\title{
References
}

Freedom House. 2018. “Mozambique Profile.” Freedom in the World 2018. Accessed 3 January 2019. https://freedomhouse.org/report/freedom-world/2018/mozambique

Geffray, Christian, and Adelaide Odete Ferreira. 1991. A Causa Das Armas: Antropologia Da Guerra Contemporânea Em Moçambique. Porto: Ed. Afrontamento.

Harrison, Graham. 1995. "Election in Mozambique." Review of African Political Economy 22, no. 63: 115-118. DOI: 10.1080/03056249508704106

Kalyvas, Stathis N. 2001. ““New” and "Old” Civil Wars: A Valid Distinction?” World Politics54, no. 01: 99-118. doi:10.1353/wp.2001.0022.

Lyons, Tanya. 1999. Guns and Guerrilla Girls: Women in the Zimbabwean National Liberation Struggle. Trenton NJ: Africa World Press.

Mack, Andrew. 1983. "Why Big Nations Lose Small Wars: The Politics of Asymmetric Conflict." Power, Strategy and Security. doi:10.1515/9781400886326-008.

Manning, Carrie L. 1998. "Constructing Opposition in Mozambique: Renamo as Political Party." Journal of Southern African Studies24, no. 1: 161-89. doi:10.1080/03057079808708571.

- - 2002. The Politics of Peace in Mozambique: Post-conflict Democratization, 1992 2000. Westport, CT: Praeger.

Schafer, Jessica. 2007. Soldiers at Peace: Veterans and Society after the Civil War in Mozambique. New York, NY and Basingstoke, UK: Palgrave Macmillan.

Vines, Alex. 1991. Renamo: Terrorism in Mozambique. York: Centre for Southern African Studies, Univ. of York

Waterhouse, Rachel, and Gil Lauriciano. 1993. "Mozambique Peace Process Bulletin.” October. https://www.open.ac.uk/technology/mozambique/sites/www.open.ac.uk. technology.mozambique/files/pics/d75952.pdf.

Weinstein, Jeremy M. 2007. Inside Rebellion: The Politics of Insurgent Violence. Cambridge: Cambridge University Press.

Wood, Elisabeth Jean. 2001. "The Emotional Benefits of Insurgency in El Salvador." Passionate Politics: 267-81. doi:10.7208/chicago/9780226304007.003.0016

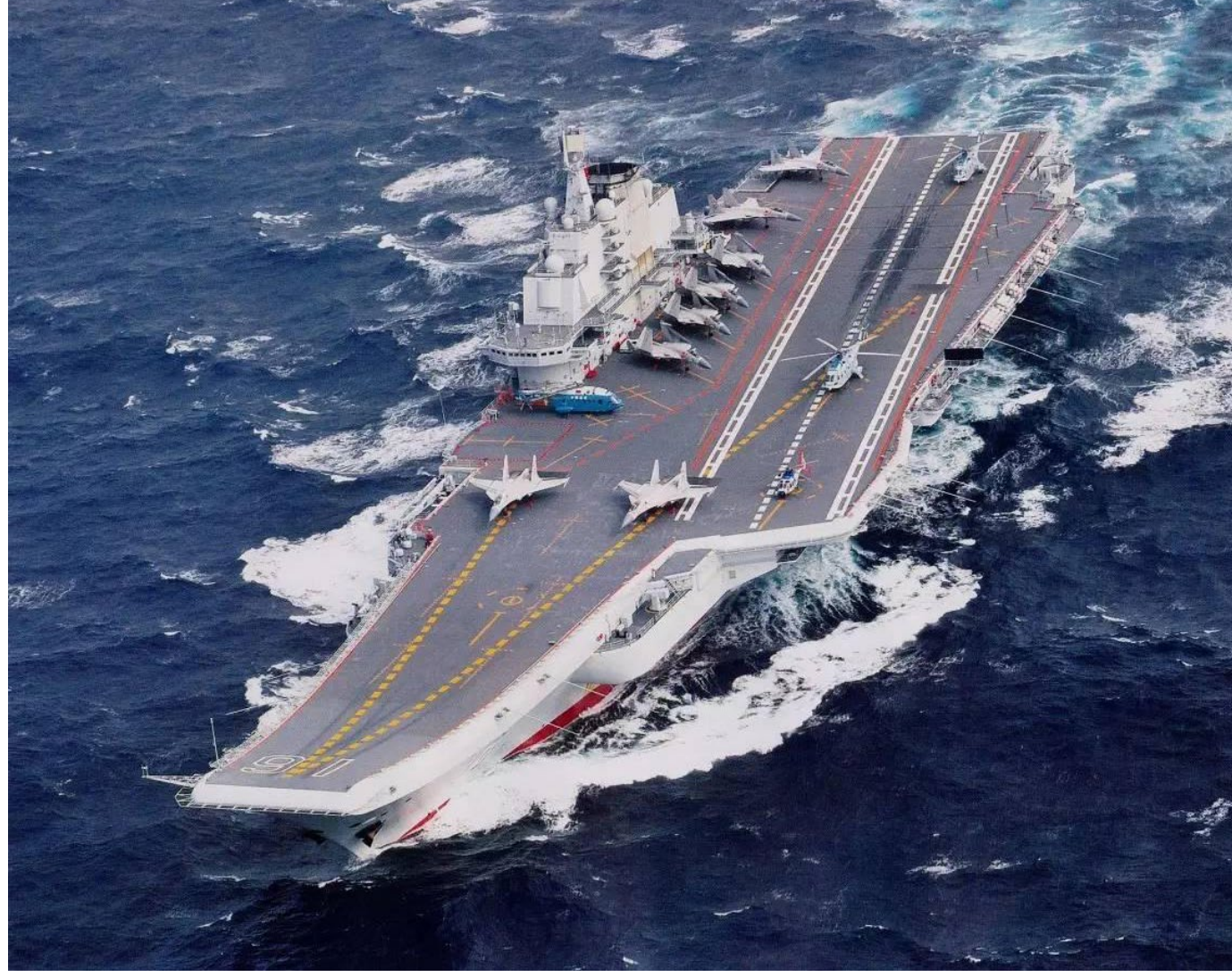

\section{Fishery Depletion and the Militarization of the South China Sea}

\author{
Jaymes Mackinnon
}

edited by Ewa Nizalowska and Rachel Nixon 
Cover art: China's navy ("Liaoning" ship) in South China Sea in April 2018 Source: http://k.sina.com.cn/article_1894445180_70eaf07c001004xy9.html

This article was submitted to course POLI 360: War and Peace.

\section{Abstract}

Fishery depletion is a driving force in the militarization of the South China Sea. Using Garrett Hardin's theory "the tragedy of the commons" as an analytical lens, this paper explores the relationship between the lack of legitimate territory designations and the illegal overexploitation of wild fish stocks. It argues that China, as the regional hegemon, has triggered conflicts by pursuing an agenda of maritime territorial expansionism. Some Southeast Asian countries, affected by these resource-driven incursions, defend their exclusive economic zones through military buildup. Therefore, the rising violence and decreasing availability of fish force some non-commercial fishermen to pursue piracy as an alternate form of income. The findings of this paper suggest that increased militarism of the South China Sea has not only predominantly affected the lives of non-commercial fishermen but also negatively impacted the regional environmental health. In the future, without multilateral resource management, this militarization will only worsen.

\section{Introduction}

T $\mathrm{n}$ the last eight years, the South China Sea has exploded with incidents of violent clashes between fishermen and coast guards, resulting in the deaths of hundreds of civilians (Boston Global Forum 2015, 14). Simultaneously, over the course of the last two decades fish catch rates have diminished between 66 to $75 \%$, placing millions of people in precarious economic conditions (South China Sea Working Group 2017). How have reduced fish stocks affected geopolitical relationships between coastal Southeast Asian nations competing for natural resources? First, I will draw upon literature on the driving causes of interstate conflict, arguing that shared resources create added pressure on closely situated states grappling with territorial disputes. Next, I situate the nature and importance of fisheries in the South China Sea and the anthropogenic threats to their existence. Subsequently, I will examine Chinese naval expansionism and its impact on neighbouring nations as an example of conflict induced by fish stock depletion on the interstate level. I will then analyze the role of fishery collapse in piracy on the South China Sea, as an example of resource-driven conflict on the subnational level. Finally, I will address the socioeconomic, environmental and security implications of increased militarism in the South China Sea. This essay will identify the importance of fish stock depletion, by exploring how militarization of the South China Sea threatens interstate and subnational relationships within systems of ambiguous control.

\section{Collective Action and Unresolved Territorial Disputes}

In geopolitical regions with unresolved territorial disputes, the issue of resource management poses a crucial collective action problem with the power to exacerbate existing fragilities in the system. Substantial work has been done on the link between territorial disputes and interstate conflict. Scholars such as Paul Hansel and John Vasquez argue that geographical proximity gives nations incentive to engage in conflict, and the significance of border sovereignty in the global system forces target states to respond, despite potential risks (Carter 2010, 969-987). This claim is backed up by Vasquez's research findings that between 1648 and 1990 , approximately $79 \%$ of wars were fought over territory disputes (Carter 2010, 969-987). Close proximity between states is further complicated when they share a common pool of resources, as understood through Garrett Hardin's collective action theory known as 'the tragedy of the commons.' Within this framework, misuse of natural resources occurs when rational actors participating in a system of shared reserves prioritize their own utility instead of considering what is beneficial for the collective, leading to the inevitable degradation of the common resource (Hardin 1968, 162). As Hardin argues, "freedom in a commons brings ruin to all." $(1968,162)$ By placing literature on territorial disputes in dialogue with Hardin's "tragedy of the commons", I argue that states with unresolved territorial disputes are simultaneously more likely to engage in violent conflict and degrade the common resources under their stewardship. In the South China Sea, ambiguous control of territory - and, by proxy, the resources within these territories - has forced states to respond with growing urgency to secure through military buildup what they perceive as their legitimate resources.

Employing Hardin's theory, legitimate ownership designations increase in importance as resources dwindle; the South China Sea has long been an area of complex overlapping zones of control. The South China Sea is an important strategic passageway between the Indian and Pacific Oceans, surrounded by the borders of six sovereign states: China, Vietnam, Malaysia, Brunei, Indonesia, and the Philippines, each of which seek to protect their sovereignty and exclusive economic zones (EEZ) (Rosenberg 2009a, 49-50). Under the United Nations Convention of the Law of the Sea (UNCLOS), each state has exclusive economic rights to up to 200 nautical miles from their shorelines, as well as 350 nautical miles of continental shelving (Boston Global Forum $2015,3)$. Nevertheless, China has historically claimed the rights of $90 \%$ of the sea through their infamous "nine-dash line" which cuts into the EEZ of 
other states, on the proclaimed basis of traditional fishing grounds (Lopez 2016). To further complicate matters, in the Paracel Islands, Macclesfield Bank, Scarborough Shoal, and the Spratly Islands, sovereignty has been declared by two or more states in the region (Boston Global Forum 2015, 1). In July of 2016, the Permanent Court of Arbitration ruled that, under UNCLOS, China had no viable claim to the area within the "nine-dash line" and that by failing to recognize other exclusive economic zones, it was infringing on the sovereignty of neighbouring nations (Montgomery 2016). China has rejected this ruling, stating "[it] will neither acknowledge it nor accept it", thus leaving the territory rights of the sea unclear (Schofield 2016, 7).

In addition to the territory of the South China Sea, the valuable resources within the regional ecosystem are also highly contested. Though the exact amount of hydrocarbon within the South China Sea is disputed, the prospect of oil and gas reserves within the region is profitable enough to raise tensions between states (Storey and Lin 2016, 3). The most well-known valuable resources within the South China Sea are wild fish stocks — an extremely difficult natural resource to assign ownership to. Unlike a plot of land or a body of water, determining the legitimate rights to fish is near impossible due to the migratory nature of most of the stocks. Many species within this common pool have migration patterns so vast that no single country could possibly work to manage the stocks alone (Rosenberg 2009b, 67). Unilateral conservation of South China Sea fisheries has trickle-down effects for policymakers attempting to set sustainable catch standards. Independent groups seeking to certify specific stocks as sustainable, such as the Marine Stewardship Council, are unable to do so when self-reported numbers from states mask declines (Rosenberg 2009b, 76). The combination of unresolved sovereignty issues and ambiguous control of resources makes the South China Sea a hotbed for geopolitical conflict.

\section{The State of Fish Stocks in the South China Sea}

The fisheries of the South China Sea are crucial to the global economy and regional livelihoods of millions of people, and they are currently at risk of an anthropogenic collapse. The fish industry is a global economic powerhouse which supports the livelihoods of 1.5 billion people, $97 \%$ of whom reside in developing countries (Thomas 2017, 81). At 3 million square kilometers, the South China Sea is relatively small compared to other economically and politically important bodies of water. Despite its size, 55\% of the world's fishing ships work in the South China Sea and in 2012 it provided $2 \%$ of the world's catch (Schofield 2016, 2). For people living in the area, the fishing industry provides employment, security, and an affordable source of protein, leaving millions at risk of malnutrition if stocks decline (Storey and Lin 2016, 3).

Overexploitation of fisheries has increased tremendously with the growth of coastal urban communities. Increased traffic and use of post-1970s bottom trawling methods in combination with land pollution from developing cities have caused fish stocks to decline by 70-95\% since the 1950s (Rosenberg 2009b, 2; Schofield, Sumaila and Cheung 2016, 2). The coral reefs located in the South China Sea have been in decline at a rate of $16 \%$ per decade, which could have devastating effects on the fish stocks (Schofield, Sumaila, and Cheung 2016, 2). This rapid coral decline is in part due to the direct destruction of reefs through giant clam poaching and the building of artificial islands-two activities the Court of Arbitration accused China of authorizing in a July 2016 case (Montgomery 2016). Fish larvae are spread through currents that travel between reefs; the health of the South China Sea reefs is crucially interconnected. If one reef collapses, the chances that the larvae will survive decreases substantially, disrupting the cycle of repopulation and threatening the stability of overall fish stocks (Bale 2016).

The collapse of fish stocks in the South China Sea poses serious security and economic concerns. Knock-on effects of climate change such as warming temperatures of the ocean and reduced reef size affect the migratory patterns of fish, causing them to diverge from their normal habits and skew into new territories (Thomas 2017, 55). Because of reduced availability of fish and changes to their migratory patterns, fishermen are forced to fish outside of their assigned sovereign limits, moving into zones of dispute if they hope to sustain a living (Bale 2016). Losses attributed to illegal fishing practices are estimated to be around $\$ 25$ billion annually, and will only increase as the population of Southeast Asia grows in numbers and affluence (Lopez 2016). In order to accurately monitor stocks, UNCLOS legally obligates states with overlapping zones to manage the environment together (Rosenberg 2009b, 70). However, due to intentional misreporting and disagreements over territorial zones of control, multilateral management has failed, and illegal overfishing remains rampant (South China Sea Working Group 2017). Fish depletion serves as a crucial threat multiplier and potentially destabilizing force in an already terse area of control.

\section{Interstate Conflict: Chinese Expansionism}

China's incursion into other sovereign zones in the South China Sea has not been driven by sustenance-related motivations. However, the increasing urgency of depleted fish stocks has escalated the conflict from a matter of diplomacy into an armed fight on all sides. In the last decade, the Chinese government expanded its fishing fleet into a 200,000 vessel-strong cohort in an effort to establish regional hegemony (South China Sea Working Group 2017). These aspirations are recognized internationally, as demonstrated by the commander of the United States Indo-Pacific Command, Adm. Philip S. Davidson, who stated in March 2018 that "China is now capable of controlling the South China 
Sea in all scenarios short of war with the United States." (Myers 2018) These commerce ships act as a covert maritime militia to protect the Navy in future warfare, while also serving as proxies for territorial control (Kraska and Monti $2015,450)$. In exchange for their commitment, fishermen receive military training, state subsidies for equipment and fuel, and coast guard protection while at sea (Krsaka and Monti 2015, 452).

The program is rooted in both economic and nationalist needs. China is already the largest consumer of fish globally, with per capita consumption averaging at 80 pounds per year - double the global average (Denver 2016). With a growing population and increasing wealth, the Chinese government needs to secure as many food resources as possible to sustain its country, including its billion-dollar fishing industry. For local fishermen, commercial fishing has depleted the stocks within China's exclusive economic zone, forcing them to travel up to 500 kilometers away from China in order to find sources of fish-sometimes flying another nation's flag in order to avoid detection (Lopez 2016). State subsidies, training, and protection allow them to safely secure their livelihoods. However, this sea-bound expansion isn't just an economic move on the part of the Chinese government. The maritime militia is an extension of the "people's war" philosophy, in which the lines between civilian and military sectors are blurred in order to link the cause of the individual to the state (Kraska and Monti 2015, 455). When asked about government involvement in the fishing industry, one Chinese fisherman expressed gratitude for protection in contested zones, while also describing his job as a means to complete his patriotic duty, saying "it is our water, but if we don't fish there how will we claim it is our territory?" (Denver 2016)

China's attempts to extend regional control have not gone unnoticed by neighbouring countries affected by the growing presence of Chinese vessels. The smaller nations of the South China Sea have been actively fighting back against China's territorial expansionism, in part due to resource anxiety. The presence of Chinese fishing boats accompanied by the coast guard puts added pressure on fisheries already nearing collapse, driving out smaller fisherman with legal rights to the waters. China's lack of adherence to the Court of Arbitration's July 2016 ruling has boosted the rest of the coastal states to match Chinese military might with their own armed resistance (Schofield, Sumaila, and Cheung 2016, 2). Vietnam, Malaysia, the Philippines, and Indonesia have begun using their navies in order to stop foreign ships from infiltrating their EEZs, and, in some cases, using explosives to destroy any foreign ships approaching their territory (Thomas 2015, 55). The Philippines is adding 100 new patrol vessels to their current fleet of twenty in an effort to stop foreign ships from trespassing in their zones of control, with a particular emphasis on protecting breeding zones (Lopez 2016).
Tensions have escalated beyond the symbolic action of military buildup. In recent years, animosity has manifested in the rise of violent maritime attacks. Armed naval conflicts have long been a staple of the South China Sea. However, since the turn of the century, the frequency of violent conflicts has escalated to the point that use of force is considered routine (Boston Global Forum 2015, 14). Incidents have ranged from aggressive ramming of vessels to full on shootouts. In one notable 2012 case, a dispute between the Philippines Navy and a group of Chinese vessels illegally fishing in the contested Scarborough Shoal are resulted in a ten-week standoff (Bale 2016). The environmental pressure of fishery collapse has pushed coastal states of the South China Sea to resort to increased militarism in order to preserve their food security and national security.

\section{Subnational Conflict: Piracy in the South China Sea}

The steady decline of fish stocks in the South China Sea has created a substantial conflict dynamic in the form of piracy. Piracy can be understood as one symptom of a system with serious socio-economic and geopolitical concerns, reflecting the breakdown of territorial control, poverty, corruption and cooperation issues between nations (Liss 2014, 2). In a 2015 study on global piracy rates, the West Indian Ocean was identified as having sixteen total reported incidents with 306 seafarers having experienced attacks. In comparison, in the same year Southeast Asia had 200 reported piracy attacks involving a total of 3574 seafarers (Dussey and Noakes 2015,6). While these statistics reflect the difference in sheer volume of vessels traveling these two bodies of water, they also indicate that piracy remains a persistent problem in the South China Sea. Of the various forms of piracy, the most popular technique in the South China Sea is hijacking-a practice in which the crew is overpowered by pirates and cargo is stolen (Ong-Webb 2015, 2-4). Politically and ideologically-driven attacks have been infrequent in the South China Sea, indicating that the culprits are driven by a primarily economic need (Rosenberg 2009a, 49-50). The manipulation of lax sea laws to facilitate piracy has resulted in millions of dollars of cargo stolen, thousands of murders, and the perpetration of other crimes through the use of "phantom ships", making piracy a regional problem with serious global implications (Ong-Webb 2015, 48).

Fishery depletion has been a key factor driving low-income fisherman to piracy. Subsistence fishermen who rely on their catch to feed their families and make a living have had their livelihoods threatened by diminishing stocks. In the Philippines alone, ten out of the thirteen designated fishing zones have been overfished to the point of collapse, with daily catches falling from approximately twenty kilograms per day in 1970 to 4.76 kilograms daily in 2016 (Lopez 2016). Small hauls combined with the growing armed threat at sea in the form of 
militarized Chinese fishing vessels has driven impoverished fishermen to pursue alternative sources of income in order to survive. Of the various options for non-traditional employment, piracy is a logical choice for former fishermen. Most already possess the resources and skills necessary to succeed at sea: local territorial knowledge, naval skills, and equipment (Liss 2014, 48).

Historically, when non-commercial fishermen are pushed from their traditional lines of work, instances of piracy increase. There was a significant upsurge in pirate attacks in the years following the 1997 financial crisis in Asia when unemployment levels peaked and impoverished fishermen sought alternative sources of income equipment (Liss 2014, 1). Since the late 2000s, the South China Sea has experienced another upward trend in pirate activity. These attacks are similar to those of the 1990s, characterized by indiscriminate looting of merchant ships regardless of type or national affiliation, with the exception of massive commercial vessels equipment (Liss 2014, 4). Essentially, piracy increased when fishermen's livelihoods were at stake, be it from the financial crisis or dying fisheries. The indiscriminate nature of piracy is crucial to understanding the factors which drive people into this form of subnational insurgency. The actions of maritime terrorists depend upon the notion that sovereignty is irrelevant and in the territorially contentious zone of the South China Sea, weak sovereignty is a wealth to be exploited (Ong-Webb 2015, 42).

\section{Complications of Increased Militarism}

Increased militarism linked to fishery depletion has created a series of socioeconomic, environmental, and security issues which threaten the stability of Southeast Asia. The effects of resource scarcity and militarization on daily life have disproportionately affected poor locals. Those most affected are small, noncommercial fishermen who are forced to reconcile with the increasing threats to their illegal designated stocks, while wielding attacks from state patrollers and pirates. Typically, fishermen will board their vessels for months on end, making raids on their ships not only an attack on their workplaces but on their homes (Liss 2014, 1). Moreover, increased clashes have led to the collapse of another sector crucial to the livelihoods of locals to the SCS: tourism. Sparked by concerns about piracy and violence, some governments have issued advisories against traveling to areas bordering the South China Sea, such as the government of the United Kingdom warning citizens to avoid the Southern Sulu islands of the Philippines (Liss 2014, 1; United Kingdom 2018). These warnings spread fear amongst potential visitors and make it difficult for locals to find foreign investors for their businesses (Liss 2014, 21).

The rise of armed conflict has had a series of residual environmental effects, which only intensify the foundational problem of depleted resources. More boat traffic not only increases the risk of political clashes, it also creates more pollution; the more tankers in the South China Sea, the more waste is being discarded into the ocean (Singh 2016). Additionally, by limiting the ability of fishermen to hunt in their established patterns, commercial fisheries and Chinese maritime militias have forced subsistence fishermen to use creative means in order to survive. For example, some fishermen have turned to methods such as "blast fishing", in which homemade bombs are set off underwater to kill mass amounts of fish at a distance (Bale 2016). Others have turned to "cyanide fishing", a practice wherein fishermen squirt their catch with poison in order to stun them. Some fishermen have abandoned the sea completely and have instead taken to burning down coastal jungles in an attempt to forge rice fields, with little success (Jacobs 2017). Each of these tactics cause more damage to the environment than line or net fishing. However, they have become necessary means of survival in the absence of traditional options.

The more militarized a region becomes, the less likely a multilateral solution is possible and without multilateral resource management fishery depletion will only intensify. Without the resolution of the crucial issue of ambiguous territorial control, no further progress can be made in the realm of resource conservation. The importance of a clear cooperation agreement extends to the issue of violence reduction. With the exception of surface level information sharing, there have been no meaningful anti-piracy agreements between Southeast Asian countries affected by pirate activity. Most importantly, there have been no anti-piracy efforts addressing the baseline factors that force people into piracy: poverty, overfishing, and lack of employment opportunities outside of the fishing industry (Liss 2014, 11). With the exception of China, all countries involved in territory disputes have expressed or implied a willingness to meet in order to solve the conflicts associated with UNCLOS (Boston Global Forum $2015,14)$. However, without the support of China-the biggest fish producer and consumer in the world-stabilizing the fisheries and by extension the regional politics is impossible.

\section{Conclusion}

In systems with contested territorial control, resource management is a crucial collective action problem, which can create added conflict if not managed carefully. In the case of Southeast Asia, the collapsing fishing industry has exacerbated disagreements over territorial rights because, in order to protect their proportion of the common good, countries are forced to deal with the regional hegemon by increasing military buildup. Furthermore, depleted resources have driven subnational actors to seek alternative sources of income through piracy, contributing to the militarization of the South China Sea. This regional militarization has disproportionately affected the lives of poor locals, created more environmental degradation, and inhibited the possibility of a multilateral resolution. As it stands, the six coastal nations of the South China Sea must work together to overcome the tragedy of the commons, in order to 


\section{References}

Bale, Rachel. 2016. "One of the World's Biggest Fisheries Is On the Verge of Collapse." National Geographic. August 29. https://news.nationalgeographic.com/2016/08/ wildlife-south-china-sea-overfishing-threatens-collapse/.

Bodanac, Nicholas, Daniel Hyslop, and Rodolpho Valente. 2016. "Understanding the Climate-Conflict Nexus From a Humanitarian Perspective." OCHA Policy and Studies Series, May. https://www.unocha.org/sites/unocha/files/Understanding the climate-conflict nexus.pdf.

Boston Global Forum. 2015. "Recent Trends in the South China Sea Disputes." Boston Global Forum, June. https://bostonglobalforum.org/wp-content/uploads/RecentTrends-changes-in-the-South-China-Sea-Disputes.pdf.

Carter, David B. 2010. "The Strategy of Territorial Conflict." American Journal of Political Science 54, no. 4: 969-987. doi:10.1111/j.1540-5907.2010.00471.x

Denyer, Simon. 2016. "How China's Fishermen Are Fighting a Covert War in the South China Sea." The Washington Post. April 12. https://www.washingtonpost.com/world/ asia_pacific/fishing-fleet-puts-china-on-collision-course-with-neighbors-in-southchina-sea/2016/04/12/8a6a9e3c-fff3-11e5-8bb1-f124a43f84dc_story.html?utm_ter$\mathrm{m}=.20 \mathrm{a} 939078 \mathrm{ebb}$

Dussey, Robert, and Giles Noakes. 2015. "The State of Maritime Piracy." Oceans Beyond Piracy. http://obp.ngo/sites/default/files/State_of_Maritime_Piracy_2015.pdf.

Hardin, Garrett. 1968. “The Tragedy of the Commons.” Science Magazine, December 13. http://science.sciencemag.org/content/sci/162/3859/1243.full.pdf.

Jacobs, Andrew. 2017 "China’s Appetite Pushes Fisheries to the Brink." The New York Times. April 30. https://www.nytimes.com/2017/04/30/world/asia/chinas-appetite-pushes-fisheries-to-the-brink.html.

Kraska, James, and Michael Monti. 2015. “The Law of Naval Warfare and China's Maritime Militia." International Law Studies: US Naval War College, 91. http://digital-commons.usnwc.edu/cgi/viewcontent.cgi?article=1406\&context=ils.

Liss, Carolin. 2014. "Assessing Contemporary Maritime Piracy in Southeast Asia: Trends, Hot Spots and Responses." Peace Research Institute Frankfurt 125. https:// www.hsfk.de/fileadmin/HSFK/hsfk_downloads/prif125.pdf.

Lopez, Leslie. 2016. "South China Sea - Part One: Fish Wars." The Straits Times. April 3. http://www.straitstimes.com/asia/south-china-sea-fish-wars.

Montgomery, Scott L. 2016. "What's at Stake in China's Claims to South China Sea?" The Conversation. July 14. https://theconversation.com/whats-at-stake-in-chinasclaims-to-the-south-china-sea-62472.

Myers, Steven Lee. 2018. "With Ships and Missiles, China is Ready to Challenge U.S. Navy in Pacific," New York Times, August 29. https://www.nytimes.com/2018/08/29/ world/asia/china-navy-aircraft-carrier-pacific.html

Ong-Webb, Graham Gerard. 2015. "Piracy, Armed Robbery and Terrorism at Sea: A Global and Regional Outlook." Piracy, Maritime Terrorism and Securing the Malacca Straits. https://muse.jhu.edu/chapter/667336.

Rosenberg, David. 2009a. "Political Economy of Piracy in the South China Sea." Naval War College (U.S.) 62, no. 3 (Summer): 43-58. https://www.hsdl.org/?abstract\&-
December 1). Security and International Politics in the South China Sea: Towards a Co-operative Management Regime. Rougtledge.\&ots=_31fknyp8A\&sig=zkEvAXRgY7R4FCdjYyQm6gkFXo8\&redir_esc=y\#v=onepage\&q\&f=false.

Singh, Abhijit. 2016. "Why the South China Sea is on the Verge of an Environmental Disaster," The National Interest, August 13.

Schofield, Clive H., Rashid Sumaila, and William Cheung. 2016. "Fishing, Not Oil, Is at the Heart of the South China Sea Dispute." University of Wollongoing, Faculty of Law. http://ro.uow.edu.au/cgi/viewcontent.cgi?article=3503\&context=lhapapers.

South China Sea Working Group. 2017. "A Blueprint for Fisheries Management and Environmental Cooperation in the South China Sea." Asia Maritime Transparency Initiative. September 13. https://amti.csis.org/coc-blueprint-fisheries-environment/.

Storey, Ian, and Cheung-yi Lin. 2016. The South China Sea Dispute: Navigating Diplomatic and Strategic Tensions. Singapore: ISEAS: Yusof Ishak Institute.

Thomas, Michael. 2017. "Fish, Food Security and Future Conflict Epicenters." The Centre for Climate and Security, June: 80-90. https://climateandsecurity.files.wordpress.com/2017/06/epicenters-of-climate-and-security_the-new-geostrategic-landscape-of-the-anthropocene_2017_06_091.pdf.

United Kingdom. 2018. "Malaysia," Foreign Travel Advice, August 30. https://www.gov. uk/foreign-travel-advice/malaysia 